\title{
Initial Presenting Symptoms, Comorbidities and Severity of COVID-19 Patients Attending Hmawbi and Indine Treatment Centers During the Second Wave of Epidemic in Myanmar: a Cross-sectional Study
}

Ye Minn Htun ( $\square$ dryeminnhtun85@gmail.com )

Health and Disease Control Unit https://orcid.org/0000-0002-9706-9834

Tun Tun Win

Department of Preventive and Social Medicine, Defence Services Medical Academy

\section{Aung Aung}

Department of Research and Development, Defence Services Medical School

Thant Zin Latt

Department of Research and Development, Defence Services Medical School

Yan Naung Phyo

Outpatient Department, No.3 Military Hospital (100 bedded)

Thet Min Tun

Department of Preventive and Social Medicine, Defence Services Medical Academy Nyan Sint Htun

Department of Preventive and Social Medicine, Defence Services Medical Academy Kyaw Myo Tun

Department of Preventive and Social Medicine, Defence Services Medical Academy Khin Aung Htun

Department of Surgery, Defence Services Medical Academy

\section{Research}

Keywords: Comorbidities, COVID-19, Initial presenting symptoms, Pneumonia, Severity

Posted Date: March 31st, 2021

DOI: https://doi.org/10.21203/rs.3.rs-365594/v1

License: (c) (1) This work is licensed under a Creative Commons Attribution 4.0 International License. Read Full License 


\section{Abstract}

Background: Coronavirus disease (COVID-19) caused by a highly contagious virus called severe acute respiratory syndrome coronavirus 2 emerged in China at the end of 2019 and became a major threat to health around the world. The health experts are still learning more about the detailed knowledge of the natural course and the severity of COVID-19. The study aimed to assess the prevalence and association of severity with demographic characteristics, initial presenting symptoms, and comorbidities among COVID-19 patients in Treatment Centers, Myanmar.

Methods: A cross-sectional study was conducted at Hmawbi and Indine Treatment Centers from November to December 2020 and a total of 176 adult COVID-19 patients participated in this study. Data were collected by telephone surveys using structured questionnaires. The odds ratio with a $95 \%$ confidence interval was used as a measure of association and the independent associated factors for severity (pneumonia) were investigated using logistic regression analysis.

Results: In total, $76.7 \%$ were symptomatic patients and the most common presenting symptoms were fever $43.2 \%$, loss of smell $42.0 \%$, and cough $25.6 \%$. The prevalence of comorbidity in COVID-19 patients was $35.8 \%$ and the most common comorbidities were hypertension $19.9 \%$, heart diseases $9.7 \%$, and diabetes mellitus $9.1 \%$, respectively. As a severity, $23.3 \%$ of patients had signs of pneumonia. The associated factors of pneumonia were aged 60 years and older [Adjusted Odds Ratio (AOR) $=8.82,95 \%$ Cl: 2.68-29.08], overweight or obese (AOR: $3.33,95 \%$ Cl: 1.30-8.54), current smoking (AOR: $15.29,95 \%$ Cl: 2.91-80.37), and alcohol drinking (AOR: $7.04,95 \% \mathrm{Cl}$ : 1.40-35.31). Thirty percent of symptomatic patients present with pneumonia.

Conclusions: Nearly one-fourth of the patients developed pneumonia. The COVID-19 patients who are aged 60 years and older, overweight or obese, current smokers, and alcohol drinkers should be monitored carefully during the course of treatment to reduce the disease severity.

\section{Background}

In early December 2019, the first pneumonia cases of unknown origin were identified in Wuhan, the capital city of Hubei province [1]. Since then, there has been a rapid spread of the virus in China and other countries, leading to a global public health problem. On 30th January 2020, the World Health Organization (WHO) has announced coronavirus disease 2019 (COVID-19) as a public health emergency of international concern [2]. After increasing the rapid spread of confirmed cases and continuing the risk of further global spread, the WHO declared COVID-19 as a pandemic on 11th March 2020. Since then, Europe and America had become the epicenter of the pandemic with more confirmed cases and deaths than the rest of the world [3].

The COVID-19 was a highly contagious infectious disease caused by severe acute respiratory syndrome coronavirus 2 (SARS-CoV-2), belonging to an enveloped $\beta$-coronavirus genus [4, 5]. Host cell binding and entry were mediated by the spike (S) protein of the viral envelope. The $\mathrm{S} 1$ subunit of the $\mathrm{S}$ protein 
contained the receptor-binding domain that bound to the peptidase domain of the angiotensin-converting enzyme 2 (ACE2) receptor. SARS-CoV-2 had a greater affinity for the upper respiratory tract, thus could infect the upper respiratory tract and conducted airways more easily $[6,7]$.

The SARS-CoV-2 virus was primarily transmitted from infected people to others who were in close contact through respiratory droplets, by direct contact with infected persons, or by contact with contaminated objects and surfaces [8-10]. The airborne transmission might be possible in specific settings in which procedures that generate aerosols were performed [11]. The clinical spectrum of COVID-19 could range from asymptomatic infection or mild upper respiratory tract illness to severe interstitial pneumonia with respiratory failure. The common symptoms were fever or chills, cough, shortness of breath, fatigue, muscle aches, headache, loss of taste or smell, sore throat, runny nose, nausea or vomiting, and diarrhea [1]. During the pre-symptomatic period, some infected persons could be contagious and therefore, people infected with COVID-19 could transmit the virus before significant symptoms developed [12, 13].

Certain comorbidities (including diabetes, heart diseases, chronic kidney disease, and obesity) were strongly related to COVID-19 hospitalization and severity. Some studies demonstrated that comorbidities including hypertension, diabetes, and cardiovascular diseases, chronic lung diseases, chronic kidney disease, and cancer might be predictors for the poor prognosis in COVID-19 patients [14]. Older people with underlying medical problems like cardiovascular disease, diabetes, chronic respiratory disease, and cancer were more at risk of developing a serious illness and required referral for intensive care due to their low immune status $[1,15-19]$.

As of 7th March 2021, the total number of confirmed cases was 116 million with approximately 2.5 million deaths in 219 countries and territories around the world [20]. In Myanmar, the first COVID-19 reported cases were identified on 23rd March 2020 and the total confirmed cases were 142,023 with 3,200 deaths through 7th March 2021. The confirmed cases were increasingly reported in Yangon Region followed by Mandalay, Bago, Ayeyarwaddy, and Rakhine State [21, 22]. To control the disease spread, the government performed mitigating measures such as an increase in testing capacity, expansion of treatment centers and quarantine facilities, restriction of public gatherings, closing international flights, closing restaurants and daycare facilities [22].

Although focusing on the public health measures like social distancing, the prohibition of public gatherings, and increased use of face masks to control the spread of COVID-19, these measures alone were uncertain to stop the pandemic due to the highly contagious nature of the disease. The continuation of learning more about the natural course of COVID-19, clinical presentation, comorbidity, and severity of disease was critical for healthcare system preparedness $[23,24]$. To better understand and adequately manage this novel threat, exploring detailed knowledge on clinical courses of infected patients and clarifying the severity were required [25]. The aim of the study has therefore been to identify initial presenting symptoms, comorbidities, and severity of COVID-19 patients in Treatment Centers.

\section{Methods}




\section{Study design and population}

A cross-sectional study was conducted among COVID-19 patients attending at Hmawbi and Indine Treatment Centers from November to December 2020. All patients with confirmed SARS-CoV-2 infection by a positive result on reverse transcription polymerase chain reaction (RT-PCR) testing of a nasopharyngeal sample were included in this study.

\section{Study area}

The study was carried out at Hmawbi and Indine Treatment Centers, which provided the medical services to the confirmed COVID-19 patients, established in the second wave of the COVID-19 epidemic in Myanmar. The Treatment Centers were located in Hamwbi and Hlegu Townships, Yangon Region, Myanmar.

\section{Sample size determination and sampling technique}

The sample size was calculated using a single population proportion formula [26] with an assumption of $95 \%$ Confidence Intervals (CI), $7 \%$ margin of error, and $33.9 \%$ of COVID-19 patients with comorbidity were severe [27]. Base on this assumption, the final sample size was estimated as 176. All adult COVID-19 patients attending at two COVID-19 Treatment Centers during the study period were selected. The patients who were transferred to an intensive care unit and those who did not give informed consent were excluded.

\section{Operational definition}

Current smoking was defined as an adult who has smoked 100 cigarettes in his or her lifetime and who currently smokes cigarettes. Alcohol drinking was defined as an adult who took at least 12 drinks in the past year but 3 drinks or fewer per week, on average over the past year. A contact person was defined as a person who experienced any one of the following exposures during the 2 days before and the 14 days after the onset of symptoms of a probable or confirmed case: face-to-face contact with a probable or confirmed case within 1 meter and for more than 15 minutes, direct physical contact with a probable or confirmed case, and direct care for a patient with probable or confirmed COVID-19 disease without using proper personal protective equipment [28]. Comorbidity was a presence of more or additional medical conditions or diseases in COVID-19 patients. The presenting symptom was a symptom or group of symptoms about which the COVID-19 patient initially complains or from which he/she sought relief (such as fever, muscle ache, cough, sore throat, dyspnoea, etc.).). The severity of COVID-19 was defined as an adult patient with clinical signs of pneumonia (fever, cough, dyspnoea, fast breathing) [28] which was diagnosed by a physician and radiologist, and it was categorized as pneumonia and no pneumonia.

\section{Data collection and procedure}

The data were collected by three interviewers through telephone survey method using a structured questionnaire that included personal characteristics (sex, age, state and region, township, education, 
occupation, height, weight, body mass index (BMI), smoking status, alcohol drinking, contact with known COVID-19 cases, travelling history to abroad, and travelling history to townships under stay at home order), comorbidity (hypertension, diabetes mellitus, coronary heart disease, chronic respiratory disease, cerebrovascular accident, cirrhosis of liver, hepatitis $B$ virus infection, hepatitis $C$ virus infection, chronic kidney disease, haematological disease, and cancer), and initial presenting symptoms (fever, chills, difficulty in breathing, fatigue, muscle aches, headache, loss of smell, loss of taste, sore throat, runny nose, nausea or vomiting, diarrhea). The outcome variable, severity (pneumonia) of COVID-19 patients, was reviewed from patients' records. The participants were explained about the purpose of the study and then a telephone survey was conducted after receiving verbal informed consent.

\section{Statistical analysis}

The collected data were entered into Microsoft Excel 2016 and exported to IBM SPSS Statistics for Windows, Version 23.0. (Armonk, NY: IBM Corp) for analysis. Descriptive statistics were presented as frequency and percentages for categorical variables and mean (standard deviation, SD) for continuous variables. Bivariable logistic regression analysis was performed to assess the relative impact of the predictor variables on the outcome variable. To control for potential confounding factors, multivariable

logistic regression analysis was performed. All independent factors of bivariable regression analysis were candidates for the multivariable logistic regression model. The results of group comparisons of risk factors and pneumonia were expressed as Adjusted Odds Ratio (AOR) with $95 \% \mathrm{Cl}$ and a $p$ value was set at $<0.05$ for statistical significance.

\section{Results}

A total of 176 COVID-19 patients were included in the study. Table 1 showed the demographic characteristics of COVID-19 patients. Among them, 87 (49.4\%) were female and $89(50.6 \%)$ were male. The mean $( \pm S D)$ age was 42.52 ( \pm 16.34 ) years with a range of $18-86$ years and $150(85.2 \%)$ patients were younger than 60 years. Most of the patients, 164 (93.2\%), were from Yangon Region and among them, $116(70.7 \%)$ patients were from North District. In total, 78 (44.3\%) patients had a high school education level and 105 (59.7\%) patients were employed. In BMI of patients, 112 (63.6\%) were healthy or normal weight, 36 (20.5\%) were overweight and 10 (5.7\%) were obese. Thirteen (7.4\%) patients were current smokers and $10(5.7 \%)$ had a history of alcohol drinking. Overall, $63(35.8 \%)$ patients had a history of contact with confirmed cases. Only two $(1.1 \%)$ and $4(2.3 \%)$ patients travelled to foreign countries and townships under stay at home order, respectively. 
Table 1

Demographic characteristics of COVID-19 patients

\begin{tabular}{|ll|}
\hline Variables & Frequency (\%) \\
\hline Sex & \\
\hline Male & $89(50.6)$ \\
\hline Female & $87(49.4)$ \\
\hline Age (year) & \\
\hline$<60$ & $150(85.2)$ \\
\hline$\geq 60$ & $26(14.8)$ \\
\hline Mean \pm SD; 42.52 \pm 16.34, Minimum 18, Maximum 86 & \\
\hline State and Region & \\
\hline Yangon & $164(93.2)$ \\
\hline Bago & $5(2.8)$ \\
\hline Rakhine & $3(1.7)$ \\
\hline Shan & $3(1.7)$ \\
\hline Mon & $1(0.6)$ \\
\hline District in Yangon Region (n=164) & \\
\hline East Yangon & $105(9.1)$ \\
\hline West Yangon & $65(36.9)$ \\
\hline South Yangon & $24(14.6)$ \\
\hline North Yangon & $9(5.5)$ \\
\hline Education & $116(70.7)$ \\
\hline Primary school education level & \\
\hline Middle school education level & \\
\hline High school education level & \\
\hline University and graduate & $(15.3)$ \\
\hline Occupation & \\
\hline Unemployed & \\
\hline Employed & \\
\hline
\end{tabular}




\begin{tabular}{|ll|}
\hline Variables & Frequency (\%) \\
\hline $\mathrm{BMI}\left(\mathrm{kg} / \mathrm{m}^{2}\right)(\mathrm{n}=173)$ & \\
\hline Underweight $(<18.5)$ & $15(8.5)$ \\
\hline Healthy or normal weight $(18.5-24.9)$ & $112(63.6)$ \\
\hline Overweight $(25.0-29.9)$ & $36(20.5)$ \\
\hline Obese $(\geq 30.0)$ & $10(5.7)$ \\
\hline Mean \pm SD; $23.12 \pm 4.09$, Minimum 14.2, Maximum 36.8 & \\
\hline Smoking status & \\
\hline No & $163(92.6)$ \\
\hline Yes & $13(7.4)$ \\
\hline Alcohol drinking & \\
\hline No & $166(94.3)$ \\
\hline Yes & $10(5.7)$ \\
\hline Contact history & \\
\hline No & $113(64.2)$ \\
\hline Yes & $63(35.8)$ \\
\hline Travel history to foreign countries & \\
\hline No & $174(98.9)$ \\
\hline Yes & \\
\hline Travel history to townships under stay at home order & \\
\hline No & \\
\hline Yes & \\
\hline
\end{tabular}

The initial presenting symptoms, comorbidities and severity of COVID-19 were described in Table 2. Of all patients, 135 (76.7\%) were symptomatic and the most common initial presenting symptoms were fever [76, (43.2\%)] followed by loss of smell [74, (42.0\%)], cough [45, (25.6\%)], muscle ache [42, $(23.9 \%)]$ and headache $[42,(23.9 \%)]$. Sixty-three $(35.8 \%)$ patients had comorbidities and the most common comorbidities were hypertension [35, (19.9\%)], cardiovascular disease [17, (9.7\%)] and diabetes mellitus [16, (9.1\%)]. As a severity, 41 (23.3\%) patients present with sign of pneumonia. 
Table 2

Initial presenting symptoms, comorbidities and severity of COVID-19 patients

\begin{tabular}{|lc|}
\hline Variables & Frequency (\%) \\
\hline Initial presenting symptom & \\
\hline Asymptomatic & $41(23.3)$ \\
\hline Symptomatic & $135(76.7)$ \\
\hline Presenting symptoms (multiple response) \\
\hline Fever & $76(43.2)$ \\
\hline Loss of smell & $74(42.0)$ \\
\hline Cough & $45(25.6)$ \\
\hline Muscle ache & $42(23.9)$ \\
\hline Headache & $42(23.9)$ \\
\hline Dyspnoea & $31(17.6)$ \\
\hline Malaise & $30(17.0)$ \\
\hline Sneezing & $29(16.5)$ \\
\hline Loss of taste & $25(14.2)$ \\
\hline Sore throat & $21(11.9)$ \\
\hline Chill & $19(10.8)$ \\
\hline Diarrhoea & $18(10.2)$ \\
\hline Nausea and vomiting & $8(4.5)$ \\
\hline Comorbidity & \\
\hline No & $113(64.2)$ \\
\hline Yes & $63(35.8)$ \\
\hline Comorbid diseases (multiple response) \\
\hline Hypertension & $35.1)$ \\
\hline Heart disease & $(19.9)$ \\
\hline Diabetes Mellitus & \\
\hline Haematological disease & $9.3)$ \\
\hline Stroke & \\
\hline
\end{tabular}




\begin{tabular}{|ll|}
\hline Variables & Frequency (\%) \\
\hline Hepatitis B virus infection & $3(1.7)$ \\
\hline Chronic lungs disease & $1(0.6)$ \\
Cirrhosis of liver & $1(0.6)$ \\
Cancer & $1(0.6)$ \\
Severity (Pneumonia) & \\
No & $135(76.7)$ \\
Yes & $41(23.3)$ \\
\hline
\end{tabular}

In bivariable logistic regression analysis, the patients who were 60 years and older (COR: $9.92,95 \% \mathrm{Cl}$ : 3.96-24.84), those with overweight or obese (BMI $\left.\geq 25 \mathrm{~kg} / \mathrm{m}^{2}\right)$ (COR: $3.88,95 \% \mathrm{Cl}: 1.84-8.20$ ), those who were current smokers (COR: 14.19, 95\% Cl: 3.69-54.65), and those who were alcohol drinkers (COR: 5.61, 95\% Cl: 1.50-20.99) were more likely to develop pneumonia (Table 3). In multivariable logistic regression analysis, the factors such as age, $\mathrm{BMI}$, current smoking, and alcohol drinking remained as the significant associated factors of pneumonia. Aged 60 years and older patients were 8.82 times more likely to get pneumonia than the younger patients (AOR: 8.82,95\% Cl: 2.68-29.08). The patients with overweight or obese were 3.33 times more likely to develop pneumonia than the patients with the counterpart (AOR: $3.33,95 \% \mathrm{Cl}$ : 1.30-8.54). The current smokers were 15.29 times more likely to get pneumonia compared with the non-smokers (AOR: 15.29: 95\% Cl: 2.91-80.37). The alcohol drinkers were 7.04 times more likely to develop pneumonia than those who were non-drinkers (AOR: $7.04,95 \% \mathrm{Cl} 1.40$ 35.31). 
Table 3

Association of severity with demographic characteristics, comorbidity and initial presenting symptoms in COVID-19 patients

\begin{tabular}{|c|c|c|c|c|c|c|}
\hline \multirow[t]{2}{*}{ Variables } & \multicolumn{2}{|l|}{ Severity } & \multirow{2}{*}{$\begin{array}{l}p \\
\text { value }\end{array}$} & \multirow{2}{*}{$\begin{array}{l}\text { COR }(95 \% \\
\mathrm{Cl})\end{array}$} & \multirow{2}{*}{$\begin{array}{l}p \\
\text { value }\end{array}$} & \multirow{2}{*}{$\begin{array}{l}\mathrm{AOR}{ }^{\dagger}(95 \% \\
\mathrm{Cl})\end{array}$} \\
\hline & $\begin{array}{l}\text { No } \\
\text { Pneumonia } \\
\text { n (\%) }\end{array}$ & $\begin{array}{l}\text { Pneumonia } \\
\text { n (\%) }\end{array}$ & & & & \\
\hline \multicolumn{7}{|l|}{ Sex } \\
\hline Female & $72(82.8)$ & $15(17.2)$ & & 1 & & 1 \\
\hline Male & $63(70.8)$ & $26(29.2)$ & 0.063 & $\begin{array}{l}1.98(0.96- \\
4.07)\end{array}$ & 0.617 & $\begin{array}{l}1.29(0.47- \\
3.55)\end{array}$ \\
\hline \multicolumn{7}{|l|}{ Age } \\
\hline$<60$ years & $126(84.0)$ & $24(16.0)$ & & 1 & & 1 \\
\hline$\geq 60$ years & $9(34.6)$ & $17(65.4)$ & $<.001$ & $\begin{array}{l}9.92(3.96- \\
24.84)\end{array}$ & $<.001$ & $\begin{array}{l}8.82(2.68- \\
29.08)\end{array}$ \\
\hline \multicolumn{7}{|l|}{ Education ${ }^{\ddagger}$} \\
\hline $\begin{array}{l}\text { University and } \\
\text { graduate }\end{array}$ & $55(84.6)$ & $10(15.4)$ & & 1 & & 1 \\
\hline Below university & $80(72.1)$ & 31 (27.9) & 0.061 & $\begin{array}{l}2.13(0.97- \\
4.70)\end{array}$ & 0.973 & $\begin{array}{l}1.02(0.37- \\
2.82)\end{array}$ \\
\hline \multicolumn{7}{|l|}{ Occupation } \\
\hline Unemployed & $55(77.5)$ & $16(22.5)$ & & 1 & & 1 \\
\hline Employed & $80(76.2)$ & $25(23.8)$ & 0.844 & $\begin{array}{l}1.07(0.53- \\
2.19)\end{array}$ & 0.794 & $\begin{array}{l}1.15(0.40- \\
3.30)\end{array}$ \\
\hline \multicolumn{7}{|l|}{$\mathrm{BMI}^{\otimes}(\mathrm{n}=173)$} \\
\hline$<25 \mathrm{~kg} / \mathrm{m}^{2}$ & $106(83.5)$ & $21(16.5)$ & & 1 & & 1 \\
\hline$\geq 25 \mathrm{~kg} / \mathrm{m}^{2}$ & $26(56.5)$ & $20(43.5)$ & $<.001$ & $\begin{array}{l}3.88(1.84- \\
8.20)\end{array}$ & 0.012 & $\begin{array}{l}3.33(1.30- \\
8.54)\end{array}$ \\
\hline
\end{tabular}

† All independent variables in bivariable logistic regression were included in multivariable logistic
regression model.

‡ Education was categorized as below university (primary, middle and high school education level) and university and graduate.

${ }^{\circledR}$ BMI was classified as $<25 \mathrm{~kg} / \mathrm{m}^{2}$ (underweight and normal weight) and $\geq 25 \mathrm{~kg} / \mathrm{m}^{2}$ (overweight and obese). 


\begin{tabular}{|c|c|c|c|c|c|c|}
\hline \multirow[t]{2}{*}{ Variables } & \multicolumn{2}{|l|}{ Severity } & \multirow{2}{*}{$\begin{array}{l}p \\
\text { value }\end{array}$} & \multirow{2}{*}{$\begin{array}{l}\text { COR }(95 \% \\
\mathrm{Cl})\end{array}$} & \multirow{2}{*}{$p_{\text {value }}^{p}$} & \multirow{2}{*}{$\begin{array}{l}\mathrm{AOR}{ }^{\dagger}(95 \% \\
\mathrm{Cl})\end{array}$} \\
\hline & $\begin{array}{l}\text { No } \\
\text { Pneumonia } \\
\text { n (\%) }\end{array}$ & $\begin{array}{l}\text { Pneumonia } \\
\text { n (\%) }\end{array}$ & & & & \\
\hline \multicolumn{7}{|l|}{ Smoking status } \\
\hline No & $132(81.0)$ & $31(19.0)$ & & 1 & & 1 \\
\hline Yes & $3(23.1)$ & $10(76.9)$ & $<.001$ & $\begin{array}{l}14.19(3.69- \\
54.65)\end{array}$ & 0.001 & $\begin{array}{l}15.29 \\
(2.91- \\
80.37)\end{array}$ \\
\hline \multicolumn{7}{|l|}{ Alcohol drinking } \\
\hline No & $131(78.9)$ & $35(21.1)$ & & 1 & & 1 \\
\hline Yes & $4(40.0)$ & $6(60.0)$ & 0.010 & $\begin{array}{l}5.61(1.50- \\
20.99)\end{array}$ & 0.018 & $\begin{array}{l}7.04(1.40- \\
35.31)\end{array}$ \\
\hline \multicolumn{7}{|l|}{ Comorbidity } \\
\hline No & $95(84.1)$ & $18(15.9)$ & & 1 & & 1 \\
\hline Yes & $40(63.5)$ & $23(36.5)$ & 0.002 & $\begin{array}{l}3.04(1.48- \\
6.23)\end{array}$ & 0.911 & $\begin{array}{l}1.06(0.39- \\
2.83)\end{array}$ \\
\hline \multicolumn{7}{|c|}{ Initial presenting symptoms } \\
\hline Asymptomatic & $41(100.0)$ & $0(0.0)$ & & - & & - \\
\hline Symptomatic & $94(69.6)$ & $41(30.4)$ & & & & \\
\hline \multicolumn{7}{|c|}{$\begin{array}{l}{ }^{\dagger} \text { All independent variables in bivariable logistic regression were included in multivariable logistic } \\
\text { regression model. }\end{array}$} \\
\hline \multicolumn{7}{|c|}{$\begin{array}{l}\text { ₹ Education was categorized as below university (primary, middle and high school education level) } \\
\text { and university and graduate. }\end{array}$} \\
\hline
\end{tabular}

\section{Discussion}

The COVID-19 mainly affects the respiratory system, and some patients required intensive care due to a rapid progression of hypoxia, pneumonia, and acute respiratory distress syndrome. This study investigated the prevalence of symptomatic, comorbidities, and severity, and the associated factors of severity in COVID-19 patients. In this study, the sex distribution was not too different and it was in line with the studies done in China $[19,29]$. The recent study reported that $(14.8 \%)$ of patients were the older age and it seemed to be consistent with the finding obtained in the China study (12.3\%) [19] and lower 
than the studies conducted in the USA (28.3\%) [30] and Germany (26.7\%) [31]. More than one-fourth of the patients $(26.2 \%)$ were overweight or obese in this study and this result was lower than the findings of studies done in Thailand (32.9\%) [32], Germany (38.2\%) [31], and China (47.5\%) [33]. The reason for these variations might be due to the difference in the socio-economic and geographical nature of the study area, variation in sample size, and distinction in lifestyle factors.

The prevalence of initial presenting symptoms $(76.7 \%)$ in the current study was lower than studies done in Thailand (94.8\%) [32] and Korea (91.3\%) [34], but higher than in the China study (70.6\%) [19]. This inconsistency might be due to variation of diagnostic and hospitalization criteria of COVID-19 patients. One explanation for the detection of nearly one-fourth of the asymptomatic patients in this study might be due to well achievement in case finding, contact tracing, and surveillance of COVID-19 cases by the healthcare providers. A substantial number of undocumented infections leading to no symptoms might enable the rapid spread of SARS-CoV-2 [35]. In Myanmar, the government expanded the testing capacity for primary contacts and imported cases as a priority of testing. All COVID-19 patients including symptomatic and asymptomatic who were confirmed by RT-PCR and Standard Q COVID-19 Antigen Rapid Diagnosis Test were hospitalized in designated hospitals. In the current study, it was surprising that loss of smell, apart from fever and cough, was one of the most common symptoms, and this finding was contrary to that of previous studies done in the same constitution reported that fatigue, sore throat, shortness of breath and rhinorrhea were the most common presenting symptoms [30, 32-34, 36].

The prevalence of comorbid diseases (35.8\%) in COVID-19 patients was higher than the findings of the studies conducted in China (15.8\%) [19] and Thailand (25.0\%) [32]. This discrepancy could be attributed to variation in the prevalence of chronic diseases across age, gender distribution, and geographic region. Non-communicable diseases (NCDs) were identified as a priority public health problem in Myanmar and cardiovascular disease was one of the NCDs with the highest impact on mortality [37]. Over 2012 to 2017, most of the admitted patients with NCDs were middle and older aged population with the median and interquartile range of $39(25-55)$ years and (51.6\%) of those were males [38]. In the current study, the most common comorbidities were hypertension and diabetes mellitus and these results supported the findings of the earlier studies conducted in hospitalized COVID-19 patients $[19,30,31,34,36]$.

As the severity of COVID-19, the prevalence of pneumonia in this study was $(23.3 \%)$ and it was agreed with the finding of other study revealed that (23.6\%) of the COVID-19 patients developed pneumonia [31]. However, it was lower than the results of the studies conducted in Thailand (38.9\%) [32], Korea (73.2\%) [34], and China (67.9\%) [19] and (83.5\%) [29], respectively. It was possible that these results were due to variability of chest imaging findings (chest radiograph or computerized tomography), the difference in criteria of patient isolation and hospitalization, and contrast to protocol and management guidelines of COVID-19 patients. The symptomatic patients tend to have severe inflammation in the lungs, which more commonly leads to disease progression. The symptomatic patients had a higher risk of developing bilateral pneumonia and less likely to show improvement of pneumonia than asymptomatic patients [19]. 
In the recent study, age was a significant determinant of pneumonia in COVID-19 patients and it might be explained by the fact that older people were particularly susceptible to develop more infections as natural immunity declined gradually at older ages. Another explanation for this finding could be that the older people might have more expression of ACE2 encoded by the ACE2 gene and have other conventional factors such as reduced immunity, poor organ function, or coexisting comorbid diseases which might have increased risk of disease severity [39]. This finding was keeping with the previous studies done in Thailand [32], China [29, 33, 36], and Korea [34] reported that older age was a potential predictive factor of pneumonia in SARS-CoV-2 infected patients.

The immune function and response in viral infections were influenced by lifestyle factors, overweight or obesity. This study confirmed that overweight or obesity was associated with the development of pneumonia in COVID-19 patients. The possible reason might be due to the fact that people with overweight or obesity might have comorbidities including metabolic diseases, cardiovascular diseases, and cancers that were susceptible to infection. Moreover, they had a significantly large amount of ACE2 receptor in adipose tissue and were more likely to SARS-CoV-2 infection, which resulted in increased viral shedding, immune inactivation, and cytokine storm [40]. This finding also supported the evidence from other studies conducted in Thailand [32], China [33], Korea [34], and Germany [31] reported that overweight or obesity patients were more likely to get pneumonia than normal weight patients.

Tobacco contains components that disrupt the normal epithelial lining of the respiratory system leading to increased oxidative injury and impairment of mucociliary clearance [41]. Smoking was also a significant predictor of pneumonia in COVID-19 patients in the current study. This could be because tobacco smoke suppressed the function of innate immune cells, including respiratory epithelium, alveolar surfactant, macrophage, neutrophils, and lymphocytes. This could make smokers were more susceptible to develop the complications of COVID-19, such as pneumonia. This result matched those observed in earlier studies done in China $[42,43]$ and Turkey $[44]$ reported that there was an association between the current smoking status and disease severity of COVID-19. However, this finding was contrary to previous studies which had evidence that smoking was not associated with the severity of COVID-19 [34, 36, 45].

The COVID-19 patients with a history of alcohol drinking were more likely to develop pneumonia than those who were non-drinkers. A possible explanation for this might be alcohol-induced oxidative stress leading to depletion of the critical antioxidant glutathione and deterioration of alveolar barrier integrity and modulation of the immune response [46]. Alcohol also had a negative impact on lung innate defense and response to lung injury with an impairment of the ability to fight infection [47]. In addition, alcohol consumption lead to over expression of ACE2 receptors, which could support the facilitated proliferation of SARS-CoV-2 into the cells [48]. This finding was accorded with the results of other studies conducted in USA [47] and Denmark [49].

There were some limitations in this study. Firstly, it was relatively difficult to establish a causal relationship between severity and independent variables due to the cross-sectional nature of this study. A longitudinal study with a larger sample size could be applied to find out the higher strength of

Page 13/19 
association. Secondly, although the results were representative of the population with the same demographic characteristics, further research using a random sampling method should be conducted to have a more representative cohort. Thirdly, the asymptomatic patients might have developed symptoms later and they could be over looked. Lastly, the patients with unrecognized or unknown comorbidity would not be detected and therefore, further studies should obtain more information about the existing unrecognized comorbid diseases in order to ascertain association.

\section{Conclusions}

In conclusion, approximately one-fourth of asymptomatic patients with test positive for COVID-19 were identified, and therefore, screening, surveillance and contact tracing should be more expand for early detection of asymptomatic people and rapid control of community spread. The prevalence of comorbidity and severity (pneumonia) in COVID-19 patients were (35.8\%) and (23.3\%), respectively. This study reapproved the association of demographic factors and lifestyle factors with the severity of COVID-19. Therefore, the healthcare providers should pay particular attention to the COVID-19 patients who were aged 60 years and older, overweight or obese, current smokers, and alcohol drinkers to detect and reduce the disease severity as early as possible.

\section{Abbreviations}

ACE 2: Angiotensin-converting Enzyme 2; AOR: Adjusted Odds Ratio; BMI: Body Mass Index; Cl Confident Interval; COR: Crude Odds Ratio; COVID-19: Coronavirus Disease; NCDs: Non-communicable Diseases; RTPCR: Reverse Transcription Polymerase Chain Reaction; SARS-CoV-2: Severe Acute Respiratory Syndrome Coronavirus 2; SD: Standard Deviation; WHO: World Health Organization

\section{Declarations}

\section{Ethics approval and consent to participate}

Ethical clearance was obtained from Ethical Review Committee of Defence Services Medical Academy. Firstly, all participants were explained about study by telephone before conducting survey and informed about their right of withdrawing the study without restriction whenever necessary. The verbal informed consent was obtained from each participant before collecting data. The agreement of participation in the study was retained by phone recording. Privacy and confidentiality of information obtained from the participants were maintained throughout the study process.

\section{Consent for publication}

Not applicable.

\section{Availability of data and materials}


The data analyzed for this manuscript are available from the corresponding author and can be made accessible upon reasonable request.

\section{Competing interests}

The authors declare that they have no competing interests.

\section{Funding}

The study was funded by the Directorate of Medical Services, Myanmar.

\section{Authors' contributions}

YMH, TTW, KMT and KAH conceptualized the study, and contributed to design and research question development. YMH, AA and YNP performed data collection. YMT, TTW and TZL carried out data analysis, interpretation of the results and providing input for preparing the first draft of the manuscript. YMH, TMT, NSH and KMT reviewed and revised the final draft of manuscript for important intellectual content. All authors read and approved the final manuscript.

\section{Acknowledgements}

We would like to acknowledge the Directorate of Medical Services for financial support. We are thankful to Dr. Kyaw Zin Nyut, Hmawbi Treatment Centre and Dr. Tay Zar Win, Indine Treatment Centre for their administrative supports. We are also grateful to all COVID-19 patients involved in this study.

\section{References}

1. Huang C, Wang Y, Li X, Ren L, Zhao J, Hu Y, et al. Clinical features of patients infected with 2019 novel coronavirus in Wuhan, China. Lancet. 2020;395(10223):497-506.

https://doi.org/10.1016/S0140-6736(20)30183-5. Epub 2020 Jan 24.

2. World Health Organization. Timeline: WHO's COVID-19 response: World Health Organization [Internet]; 2020 [cited 2020 October 7]. Available from: https://www.who.int/emergencies/diseases/novel-coronavirus-2019/interactive-timeline\#!

3. World Health Organization. Timeline of WHO's response to COVID-19 Geneva: World Health Organization [Internet]; 2020 [updated September 9, 2020; cited 2020 October 14]. Available from: https://www.who.int/news/item/29-06-2020-covidtimeline.

4. Zhu N, Zhang D, Wang W, Li X, Yang B, Song J, et al. A Novel Coronavirus from Patients with Pneumonia in China, 2019. N Engl J Med. 2020;382(8):727-33. https://doi.org/10.1056/NEJMoa2001017. Epub 2020 Jan 24.

5. Zhou P, Yang X-L, Wang X-G, Hu B, Zhang L, Zhang W, et al. Discovery of a novel coronavirus associated with the recent pneumonia outbreak in humans and its potential bat origin. bioRxiv. 2020:2020.01.22.914952. https://doi.org/10.1038/s41586-020-2012-7. 
6. Cevik M, Kuppalli K, Kindrachuk J, Peiris M. Virology, transmission, and pathogenesis of SARS-CoV-2. BMJ. 2020;371:m3862. https://doi.org/10.1136/bmj.m3862.

7. Lu R, Zhao X, Li J, Niu P, Yang B, Wu H, et al. Genomic characterisation and epidemiology of 2019 novel coronavirus: implications for virus origins and receptor binding. Lancet. 2020;395(10224):56574. https://doi.org/10.1016/S0140-6736(20)30251-8. Epub 2020 Jan 30.

8. Li Q, Guan X, Wu P, Wang X, Zhou L, Tong Y, et al. Early Transmission Dynamics in Wuhan, China, of Novel Coronavirus-Infected Pneumonia. N Engl J Med. 2020;382(13):1199-207. https://doi.org/10.1056/NEJMoa2001316. Epub 2020 Jan 29.

9. Liu J, Liao X, Qian S, Yuan J, Wang F, Liu Y, et al. Community Transmission of Severe Acute Respiratory Syndrome Coronavirus 2, Shenzhen, China, 2020. Emerg Infect Dis. 2020;26(6):1320-3. https://doi.org/10.3201/eid2606.200239. Epub 2020 Jun 17.

10. Ong SWX, Tan YK, Chia PY, Lee TH, Ng OT, Wong MSY, et al. Air, Surface Environmental, and Personal Protective Equipment Contamination by Severe Acute Respiratory Syndrome Coronavirus 2 (SARSCoV-2) From a Symptomatic Patient. JAMA. 2020;323(16):1610-2. https://doi.org/ 10.1001/jama.2020.3227.

11. World Health Organization. Transmission of SARS-CoV-2: implications for infection prevention precautions Geneva: World Health Organization [Internet]; 2020 [updated July 9; cited 2020 October 15]. Available from: https://www.who.int/news-room/commentaries/detail/transmission-of-sars-cov2-implications-for-infection-prevention-precautions.

12. World Health Organization. Coronavirus disease 2019 (COVID-19), Situation Report -73 Geneva: World Health Organization [Internet]; 2020 [cited 2020 October 15]. Available from: https://www.who.int/docs/default-source/coronaviruse/situation-reports/20200402-sitrep-73-covid19.pdf?sfvrsn=5ae25bc7_6\#: :text=The\%20incubation\%20period\%20for\%20COVID, persons $\% 20$ can\%20be\%20contagious.

13. Kronbichler A, Kresse D, Yoon S, Lee KH, Effenberger M, Shin Jl. Asymptomatic patients as a source of COVID-19 infections: A systematic review and meta-analysis. Int J Infect Dis. 2020;98:180-6. https://doi.org/10.1016/j.ijid.2020.06.052.

14. Luo L, Fu M, Li Y, Hu S, Luo J, Chen Z, et al. The potential association between common comorbidities and severity and mortality of coronavirus disease 2019: A pooled analysis. Clin Cardiol. 2020;43(12):1478-93. https://doi.org/10.1002/clc.23465. Epub 2020 Oct 7.

15. Centers for Disease Control and Prevention. Coronavirus Disease 2019 (COVID-19), Interim Clinical Guidance for Management of Patients with Confirmed Coronavirus Disease (COVID-19): Centers for Disease Control and Prevention [Internet]; 2020 [cited 2020 October 18]. Available from: https://www.cdc.gov/coronavirus/2019-ncov/hcp/clinical-guidance-management-patients.html.

16. Chen N, Zhou M, Dong X, Qu J, Gong F, Han Y, et al. Epidemiological and clinical characteristics of 99 cases of 2019 novel coronavirus pneumonia in Wuhan, China: a descriptive study. Lancet. 2020;395(10223):507-13. https://doi.org/10.1016/S0140-6736(20)30211-7. Epub 2020 Jan 30. 
17. Pan L, Mu M, Yang P, Sun Y, Wang R, Yan J, et al. Clinical Characteristics of COVID-19 Patients With Digestive Symptoms in Hubei, China: A Descriptive, Cross-Sectional, Multicenter Study. Am J Gastroenterol. 2020;115(5):766-73. https://doi.org/10.14309/ajg.0000000000000620.

18. Guan W-j, Ni Z-y, Hu Y, Liang W-h, Ou C-q, He J-x, et al. Clinical Characteristics of Coronavirus Disease 2019 in China. N Engl J Med. 2020;382(18):1708-20. https://doi.org/ 10.1056/NEJMoa2002032.

19. Li Y, Shi J, Xia J, Duan J, Chen L, Yu X, et al. Asymptomatic and Symptomatic Patients With Nonsevere Coronavirus Disease (COVID-19) Have Similar Clinical Features and Virological Courses: A Retrospective Single Center Study. Front Microbiol. 2020;11(1570). https://doi.org/ 10.3389/fmicb.2020.01570. eCollection 2020.

20. World Health Organization. COVID-19 Weekly Epidemiological Update, Situation reports, Coronavirus disease (COVID-19). World Health Organization, Geneva, 2021 March 9.

21. Ministry of Health and Sports. Coronavirus Disease 2019 (COVID-19) Situation Reports (Myanmar) Nay Pyi Taw: Ministry of Health and Sports, The Republic of the Union of Myanmar [Internet]; 2020 [cited 2020 October 15]. Available from: https://mohs.gov.mm/page/9575.

22. Ministry of Health and Sports. COVID-19 (Coronavirus Disease 2019) Acute Respiratory Disease, Surveillance Dashboard (Myanmar) Nay Pyi Taw: Ministry of Health and Sports, The Republic of the Union of Myanmar [Internet]; 2020 [cited 2020 October 15]. Available from: https://mohs.gov.mm/Main/content/publication/2019-ncov.

23. Goh KJ, Choong MC, Cheong EH, Kalimuddin S, Duu Wen S, Phua GC, et al. Rapid Progression to Acute Respiratory Distress Syndrome: Review of Current Understanding of Critical Illness from COVID-19 Infection. Ann Acad Med Singap. 2020;49(3):108-18.

24. AlTakarli NS. Emergence of COVID-19 Infection: What Is Known and What Is to Be Expected Narrative Review Article. Dubai Med J. 2020;3(1):13-8. https://doi.org/10.1159/000506678.

25. Ishiguro T, Takano K, Kagiyama N, Hosoda C, Kobayashi Y, Takaku Y, et al. Clinical course and findings of 14 patients with COVID-19 compared with 5 patients with conventional human coronavirus pneumonia. Respir Med Case Rep. 2020;31:101207. https://doi.org/10.1016/j.rmcr.2020.101207. Epub 2020 Aug 27.

26. Lwanga SK, Lemeshow S. Sample size determination in health studies: a practical manual: World Health Organization; 1991. 1-5 p.

27. Ye C, Zhang S, Zhang X, Cai H, Gu J, Lian J, et al. Impact of comorbidities on patients with COVID-19: A large retrospective study in Zhejiang, China. J Med Virol. 2020;92(11):2821-9. https://doi.org/10.1002/jmv.26183. Epub 2020 Jun 29.

28. Ministry of Health and Sports. Clinical Management Guidelines for COVID-19 Acute Respiratory Disease. Nay Pyi taw, The Republic of the Union of Myanmar 2020 August 25. 18 p.

29. Zhang S-Y, Lian J-S, Hu J-H, Zhang X-L, Lu Y-F, Cai H, et al. Clinical characteristics of different subtypes and risk factors for the severity of illness in patients with COVID-19 in Zhejiang, China. Infect Dis Poverty. 2020;9(1):85. https://doi.org/10.1186/s40249-020-00710-6. 
30. Vaughan L, Veruttipong D, Shaw JG, Levy N, Edwards L, Winget M. Relationship of sociodemographics, comorbidities, symptoms and healthcare access with early COVID-19 presentation and disease severity. BMC Infect Dis. 2021;21(1):40. https://doi.org/10.1186/s12879-021-05764-x.

31. Sacco V, Rauch B, Gar C, Haschka S, Potzel AL, Kern-Matschilles S, et al. Overweight/obesity as the potentially most important lifestyle factor associated with signs of pneumonia in COVID-19. PLoS One. 2020;15(11):e0237799. https://doi.org/10.1371/journal.pone.0237799. eCollection 2020.

32. Pongpirul WA, Wiboonchutikul S, Charoenpong L, Panitantum N, Vachiraphan A, Uttayamakul S, et al. Clinical course and potential predictive factors for pneumonia of adult patients with Coronavirus Disease 2019 (COVID-19): A retrospective observational analysis of 193 confirmed cases in Thailand. PLoS Negl Trop Dis. 2020;14(10):e0008806. https://doi.org/10.1371/journal.pntd.0008806. eCollection 2020 Oct.

33. Rao X, Wu C, Wang S, Tong S, Wang G, Wu G, et al. The importance of overweight in COVID-19: A retrospective analysis in a single center of Wuhan, China. Medicine (Baltimore). 2020;99(43):e22766. https://doi.org/10.1097/MD.0000000000022766.

34. Lee HW, Yoon SY, Lee JK, Park TY, Kim DK, Chung HS, et al. Clinical implication and risk factor of pneumonia development in mild coronavirus disease 2019 patients. Korean J Intern Med. 2021;36(1):1-10. https://doi.org/10.3904/kjim.2020.329. Epub 2020 Dec 1.

35. Li R, Pei S, Chen B, Song Y, Zhang T, Yang W, et al. Substantial undocumented infection facilitates the rapid dissemination of novel coronavirus (SARS-CoV-2). Science. 2020;368(6490):489-93. https://doi.org/10.1126/science.abb3221. Epub 2020 Mar 16.

36. Feng Z, Yu Q, Yao S, Luo L, Zhou W, Mao X, et al. Early prediction of disease progression in COVID-19 pneumonia patients with chest CT and clinical characteristics. Nat Commun. 2020;11(1):4968. https://doi.org/10.1038/s41467-020-18786-x.

37. World Health Organization. Noncommunicable Diseasescountry Profiles 2018. Geneva, Switzerland: World Health Organization; 2018. 145 p.

38. Swe EE, Htet KKK, Thekkur P, Aung LL, Aye LL, Myint T. Increasing trends in admissions due to noncommunicable diseases over 2012 to 2017: findings from three large cities in Myanmar. Trop Med Health. 2020;48:24-. https://doi.org/10.1186/s41182-020-00209-8. eCollection 2020.

39. Biswas M, Rahaman S, Biswas TK, Haque Z, Ibrahim B. Association of Sex, Age, and Comorbidities with Mortality in COVID-19 Patients: A Systematic Review and Meta-Analysis. Intervirology. 2021;64(1):36-47. https://doi.org/10.1159/000512592. Online ahead of print.

40. Ryan PM, Caplice NM. Is Adipose Tissue a Reservoir for Viral Spread, Immune Activation, and Cytokine Amplification in Coronavirus Disease 2019? Obesity (Silver Spring). 2020;28(7):1191-4. https://doi.org/10.1002/oby.22843. Epub 2020 May 31.

41. Usman MS, Siddiqi TJ, Khan MS, Patel UK, Shahid I, Ahmed J, et al. Is there a smoker's paradox in COVID-19? BMJ Evid Based Med. 2020:bmjebm-2020-111492. https://doi.org/10.1136/bmjebm2020-111492. Online ahead of print. 
42. Liu W, Tao ZW, Wang L, Yuan ML, Liu K, Zhou L, et al. Analysis of factors associated with disease outcomes in hospitalized patients with 2019 novel coronavirus disease. Chin Med J (Engl). 2020;133(9):1032-8. https://doi.org/10.1097/CM9.0000000000000775.

43. Zhang R, Ouyang H, Fu L, Wang S, Han J, Huang K, et al. CT features of SARS-CoV-2 pneumonia according to clinical presentation: a retrospective analysis of 120 consecutive patients from Wuhan city. Eur Radiol. 2020;30(8):4417-26. https://doi.org/10.1007/s00330-020-06854-1. Epub 2020 Apr 11.

44. Gülsen A, Yigitbas BA, Uslu B, Drömann D, Kilinc O. The Effect of Smoking on COVID-19 Symptom Severity: Systematic Review and Meta-Analysis. Pulm Med. 2020;2020:7590207-. https://doi.org/10.1155/2020/7590207. eCollection 2020.

45. Lippi G, Henry BM. Active smoking is not associated with severity of coronavirus disease 2019 (COVID-19). Eur J Intern Med. 2020;75:107-8. https://doi.org/10.1016/j.ejim.2020.03.014. Epub 2020 Mar 16.

46. Liang Y, Yeligar SM, Brown LA. Chronic-alcohol-abuse-induced oxidative stress in the development of acute respiratory distress syndrome. ScientificWorldJournal. 2012;2012:740308. https://doi.org/10.1100/2012/740308. Epub 2012 Dec 27.

47. Bailey KL, Samuelson DR, Wyatt TA. Alcohol use disorder: A pre-existing condition for COVID-19? Alcohol. 2021;90:11-7. https://doi.org/10.1016/j.alcohol.2020.10.003. Epub 2020 Oct 18.

48. Bilal B, Saleem F, Fatima SS. Alcohol consumption and obesity: The hidden scare with COVID-19 severity. Med Hypotheses. 2020;144:110272-. https://doi.org/10.1016/j.mehy.2020.110272. Epub 2020 Sep 16.

49. Lassen MCH, Skaarup KG, Sengeløv M, Iversen K, Ulrik CS, Jensen JUS, et al. Alcohol Consumption and the Risk of Acute Respiratory Distress Syndrome in COVID-19. Ann Am Thorac Soc. 2020. https://doi.org/10.1513/AnnalsATS.202008-988RL. Online ahead of print. 